\title{
Adaptación de Mycobacterium smegmatis ante el agotamiento de nutrientes y su efecto en la expresión de esat-6
}

\section{Adaptation of Mycobacterium smegmatis to nutrient depletion and its effect on esat-6 expression}

\author{
Héctor M. López-Péreza,d, Sixto Velarde-Félix ${ }^{b}$, Idalia Enriquez-Verdugoa, \\ Rosa Xicotencatl-Palaciosc,d, Soila M. Gaxiola-Camachoa
}

\begin{abstract}
RESUMEN
Cuando los recursos son escasos, las micobacterias detienen su crecimiento para dar paso a los genes de la adaptación. Contrariamente, cuando el crecimiento continúa bajo condiciones de estrés, se activan genes específicos de redes metabólicas para su protección. En este sentido, la proteína codificada por esat-6 (por sus siglas en inglés: early secretory antigenic target, $6 \mathrm{kDa}$ ) en Mycobacterium tuberculosis, actúa en la lisis del epitelio alveolar y membranas de los macrófagos para escapar e invadir otras células. Pero puede tener otras funciones, tales como interferir en el contacto célula-célula y transferir su ADN. En M. smegmatis, el sistema ESX-1 (por sus siglas en inglés: Secretion Ejectosoma BOX) facilita la secreción de la proteína ESAT-6, probablemente es sensible a uno o más nutrientes del medio de cultivo. Por lo que en el presente estudio se evalúan las condiciones de cultivo limitantes en nutrientes para el crecimiento de $M$. smegmatis y su relación con la expresión del gen esat-6. Los medios de cultivos probados fueron Hartmans de Bond medio mínimo (HdB), limitado en carbono (HdB $<C$ ), nitrógeno (HdB $<N$ ) y fosfato inorgánico $(\mathrm{HdB}<\mathrm{Pi})$. M. smegmatis se adapta a $\mathrm{HdB}$ medio mínimo, $\mathrm{HdB}<\mathrm{C}$ y $\mathrm{HdB}<\mathrm{N}$ y reanuda su actividad metabólica en medio fresco, pero no se expresa esat-6. En HdB<Pi M. smegmatis pierde su capacidad metabólica respecto a la resistencia alcohol-ácido y expresa esat-6. Por lo tanto, se proponen los medios de cultivo probados como modelo para la expresión génica bajo limitación por nutrientes.
\end{abstract}

PALABRAS CLAVE: Metabolismo, Aletargamiento, Adaptación, Estrés, Agotamiento de nutrientes, Mycobacterium smegmatis, esat-6.

\begin{abstract}
When resources are scarce, mycobacteria stop growing to make way for genes adaptation allow. Conversely, when growth continues under stress conditions, specific genes metabolic networks for protection are activating. In this sense, the protein encoded by esat-6 (early secretory antigenic target, $6 \mathrm{kDa}$ ) gene in Mycobacterium tuberculosis, acting in the lysis of alveolar epithelial and macrophage membranes to escape and invade other cells. But it can have other functions, such as interfering with cell-cell contact and transfer their DNA. In M. smegmatis, the ESX-1 (Secretion Ejectosoma BOX) system that facilitates secretion of ESAT-6 protein, probably it is sensitive to one or more nutrients of the culture medium. So it in the present study culture conditions limiting nutrient for growth of $\mathbf{M}$. smegmatis are evaluated and relate the expression of esat-6. Culture media tested were minimal medium Hartmans Bond (HdB), carbon-limited $(\mathrm{HdB}<\mathrm{C})$, nitrogen $(\mathrm{HdB}<\mathrm{N})$ and inorganic phosphate $(\mathrm{HdB}<\mathrm{Pi})$. M. smegmatis $\mathrm{HdB}$ adapted to minimal medium, $\mathrm{HdB}<\mathrm{C}$ and $\mathrm{HdB}<\mathrm{N}$ and resume its metabolic activity in fresh medium, but not expressed esat-6. In $\mathrm{HdB}$ <Pi M. smegmatis loses its metabolic capacity for resistance acid-alcohol and expressed esat-6. Therefore, the culture media tested as a model for gene expression under nutrient limitation is proposed.
\end{abstract}

KEY WORDS: Metabolism, Dormancy, Adaptation, Stress, Nutrient depletion, Mycobacterium smegmatis, esat-6.

Recibido el 14 de mayo de 2014. Aceptado el 9 de septiembre de 2014.

a Facultad de Medicina Veterinaria de la Universidad Autónoma de Sinaloa, Boulevard San Ángel S/N, Fraccionamiento San Benito, Predio las Coloradas, Culiacán, Sinaloa, México.

b Instituto Nacional de Investigaciones Forestales Agrícolas y Pecuarias. México. velarde.sixto@inifap.gob.mx. Correspondencia al segundo autor.

c Facultad de Medicina Veterinaria y Zootecnia de la Benemérita Universidad Autónoma de Puebla. México.

d Centro de Innovación y Desarrollo Educativo. México.

Esta investigación fue financiada con recursos del Programa de Fomento y Apoyo a Proyectos de Investigación de la Universidad Autónoma de Sinaloa. 
El agente causal de la tuberculosis está conformado por el complejo M. tuberculosis, capaz de sobrevivir y crecer dentro de los macrófagos, un ambiente hostil por la limitación de nutrientes y acidificación(1-3). Su adaptación se efectúa a través de mecanismos que le permiten detectar su entorno, regulando los genes que se expresan o reprimen durante su crecimiento y reproducción(4), que favorecen su persistencia en el hospedero(5).

Las células pueden responder a estímulos externos al iniciar un proceso que se da a partir de la unión de un efector a un receptor unido a la membrana. Este es un mecanismo de transducción, en el que los factores estresantes desencadenan una respuesta a través de la expresión de los genes, que preparan a las bacterias durante el agotamiento de los recursos $(6,7)$. Hecho que se puede observar in vitro en la fase exponencial y son decisivos para la adaptación a las condiciones que se presenten en la fase estacionaria y sobrevivir(8). Lo anterior, implica que la célula acumule protones del medio para mantener la homeostasis del $\mathrm{pH}$ en el citoplasma(9), polifosfatos para la conversión en fuentes de energía(10). En M. tuberculosis y $M$. smegmatis, además se acumula el glutamato(11) y la asparagina(12) que se relaciona con la inducción del aletargamiento de M. tuberculosis(13).

Los bacilos tuberculosos responden a situaciones de estrés por agotamiento de nutrientes, pH ácido, especies reactivas de oxígeno y nitrógeno causado por su crecimiento en los macrófagos $(7,8,14)$. Para responder a estos estímulos, las micobacterias secretan enzimas como ESAT-6 y CFP-10 $(2,15)$, que en las células del hospedero, actúan en los procesos de necrosis, tales como la lisis del epitelio alveolar y membranas de los macrófagos, induce la fragmentación del ADN y la permeabilidad de la membrana de las mitocondrias(15). Entre las funciones metabólicas de las micobacterias, se propone que regulan la transferencia de $\operatorname{ADN}(16)$.

M. smegmatis $\mathrm{mc}^{2} 155$, mutante de la cepa silvestre M. smegmatis, es 10 a 100 mil veces
Mycobacterium tuberculosis complex is a genetically related group of Mycobacterium species that can cause tuberculosis. It characterizes for its ability to survive and grow within macrophages, in a stress environment provided with nutrient limitation and acidification(1-3). Its adaptation takes place through mechanisms that allow to detect its environment, regulating gene expression or repression during growth and reproduction(4), favoring its persistence in the host(5).

The cells can respond to external stimuli by initiating a process derived from the binding of an effector to a receptor joined with the membrane. This is a transduction mechanism in which stress factors can trigger a response through gene expression, preparing the bacteria during nutrient depletion $(6,7)$. A fact that can be observed in vitro during the exponential phase and is decisive for adaptation to conditions present in the stationary phase and survival(8). This involved that the cell accumulate protons from the environment to maintain $\mathrm{pH}$ homeostasis in the cytosol(9) and polyphosphate to sustain energy(10). In addition, glutamate also accumulates in $M$. tuberculosis and $M$. smegmatis(11) and asparagine(12), which is associated with induction dormancy of $M$. tuberculosis(13).

The bacilli respond to stress conditions due to nutrient depletion, acid $\mathrm{pH}$, and reactive oxygen and nitrogen species, caused by their growth in macrophages $(7,8,14)$. In order to respond to these stimuli, mycobacteria secrete enzymes, such as ESAT- 6 and CFP-10 $(2,15)$, which in the cells of the host, act in necrosis processes, such as lysis of alveolar epithelium and membranes of macrophages, induction of DNA fragmentation and permeability of mitochondrial membranes(15). Among the metabolic functions of mycobacteria, they regulate the transfer of DNA(16).

M. smegmatis mc 2155 , mutant of $M$. smegmatis wild-type strain, is 10 to 100 times more efficiently transformed with plasmid vectors, for use in the analysis of mycobacteria function(17). 
más eficiente transformada con plásmidos, utilizada en el análisis de la función de las micobacterias(17). Por su rápido crecimiento se ha propuesto como modelo para entender los cambios que promueven la adaptación(18) y la persistencia de las micobacterias patógenas(19). Comparte 12 de 19 genes de virulencia con $M$. tuberculosis(20), entre los que se encuentran los genes esat- 6 y $c f p-10$, que codifican para las proteínas correspondientes secretadas por el sistema ESX-1 (por sus siglas en inglés: Secretion Ejectosoma BOX)(21). Converse y Cox(22) observaron el efecto de los medios de cultivo en el sistema de secreción ESX-1, por lo que proponen que este sistema puede ser sensible a uno o más nutrientes del medio de cultivo.

Durante el proceso de adaptación, los genes relacionados con redes metabólicas específicas se expresan como una respuesta al estrés ocasionado por la privación de nutrientes(23). La adaptación de las micobacterias cultivada se puede observar después de la fase estacionaria, al cambiarse a un medio de cultivo fresco reinician su actividad. Por lo que en el presente estudio se evalúan las condiciones de cultivo limitantes de nutrientes para el crecimiento de $M$. smegmatis y su relación con la expresión del gen esat- 6 .

M. smegmatis $\mathrm{mc}^{2} 155$, se creció rutinariamente a $37{ }^{\circ} \mathrm{C}$ en Middlebrook 7H11. Las alícuotas iniciales de los medios de cultivo testigos y probados, se obtuvieron por inóculo de una colonia de $M$. smegmatis en $10 \mathrm{ml}$ de medio líquido Middlebrook $7 \mathrm{H} 9$ y se creció por $24 \mathrm{~h}$ hasta media fase logarítmica (0.8-1.0 DO a $600 \mathrm{~nm}$ ).

Los medios de cultivo utilizados como control para comparar el comportamiento metabólico de los bacilos y expresión del gen esat- 6 fueron 7H9 y Sauton sin zinc, suplementados ambos con 0.5 y $6 \%$ de glicerol respectivamente y $0.05 \%$ de Tween 80, por ser medios en los que expresa el gen esat-6(22). La inoculación inicial se efectuó con $100 \mu \mathrm{l}$ del cultivo inicial en frascos de $225 \mathrm{ml}$ con $150 \mathrm{ml}$ de medio
Because of its fast growing, it has been proposed as model for understanding the changes that promote adaptation(18) and persistence of pathogenic mycobacteria(19). It shares 12 out of 19 virulence genes with $M$. tuberculosis(20), among them are esat- 6 and cfp-10 genes, which encode corresponding proteins secreted by the Secretion Ejectosoma BOX(21). Converse and Cox(22) observed the effect of culture media in the ESX-1 secretion system, for which they suggest that this system can be sensitive to one or more culture media nutrients.

During the adaptation process, genes related to specific metabolic functions are expressed as a response to stress caused by nutrient depletion(23). The adaptation of cultured mycobacteria can be observed after the stationary phase, changing to fresh culture medium where they resume their activity; therefore, in the present study, the limiting nutrient conditions for the growth of $M$. smegmatis and its relationship with esat- 6 gene expression was evaluated.

M. smegmatis $\mathrm{mc}^{2} 155$, was grown at $37^{\circ} \mathrm{C}$ in Middlebrook $7 \mathrm{H} 11$ agar. The initial aliquots of test culture and untreated control cultures were obtained by inoculum of a $M$. smegmatis colony in $10 \mathrm{ml}$ of liquid Middlebrook 7H9 medium and was grown for $24 \mathrm{~h}$ until mid-log phase (0.8-1.0 DO at $600 \mathrm{~nm})$.

The culture media used as control for comparing the metabolic behavior of bacilli and expression of esat- 6 gene and Sauton's medium without zinc, both supplemented with 0.5 and $6 \%$ of glycerol, respectively, and $0.05 \%$ of Tween 80 , for being media in which esat-6 gene expresses(22). The initial inoculation was carried out using $100 \mu \mathrm{l}$ of the initial culture in $225 \mathrm{ml}$ flasks with $150 \mathrm{ml}$ of liquid medium and were incubated at $37{ }^{\circ} \mathrm{C}$ and agitated at $250 \mathrm{rpm}$.

All assay culture media for nutrient limitation derived from $\mathrm{HdB}$ minimal medium; $\mathrm{pH} 7$ was adjusted and $0.2 \%$ of glycerol and $0.05 \%$ of 
líquido, se incubaron a $37^{\circ} \mathrm{C}$, en agitación a 250 rpm.

Todos los medios de cultivo probados para la limitación de nutrientes se derivan del medio mínimo $\mathrm{HdB}$, se ajustó el $\mathrm{pH} 7$, se adicionó, $0.2 \%$ de glicerol, $0.05 \%$ de Tween 80(24), excepto para provocar el agotamiento de $\mathrm{C}$ $(\mathrm{HdB}<\mathrm{C})$ al que se limitó el glicerol a $0.08 \%$ $(\mathrm{v} / \mathrm{v})$. Para los experimentos en los que se requirió el agotamiento de nitrógeno $(\mathrm{HdB}<\mathrm{N})$, se usó $\left(\mathrm{NH}_{4}\right)_{2} \mathrm{SO}_{4}$ a una concentración 100 veces menor $(0.15 \mathrm{mM})$ que el usado para el medio mínimo HdB. Para los experimentos limitados 100 veces menos en $\mathrm{Pi}(\mathrm{HdB}<\mathrm{Pi})$, se adicionó $\mathrm{K}_{2} \mathrm{HPO}_{4}$ a una concentración final de $0.089 \mathrm{mM}\left(0.0155 \mathrm{~g} \mathrm{~L}^{-1}\right)$ y $\mathrm{NaH}_{2} \mathrm{PO}_{4}$ a una concentración de $0.0708 \mathrm{mM}\left(0.085 \mathrm{~g} \mathrm{~L}^{-1}\right)$, para reemplazar la pérdida de capacidad amortiguadora se agregó ácido propanosulfónico 3-(Nmorfolino) (MOPS) $50 \mathrm{mM}(24)$. La fase de crecimiento y estacionaria de todos los cultivos se monitoreó a $600 \mathrm{~nm}$ DO, hasta las $144 \mathrm{~h}$ y se registró el $\mathrm{pH}$ final.

El fragmento predicho del gen esat- 6 se obtuvo por amplificación del ADN de M. smegmatis a partir de los iniciadores: F-5'ACAGGTATGGAAT TTCGCCG-3', R-5'-CAGGCAAACATTCCCGTGA-3', los cuales se diseñaron con el programa Oligo TM Software DNA Star Program. Para llevar a cabo la identificación mediante secuenciación enzimática, el producto amplificado se purificó mediante un protocolo a base de columnas de silica (QIAquick Gel Extraction Kit, QIAGEN ${ }^{\circledR}$ ), para ello, el fragmento amplificado se visualizó en el gel de agarosa al $1.2 \%$ a través de un transiluminador de luz UV y se cortó mediante un bisturí estéril, llevando a cabo el protocolo mencionado. La calidad y la cantidad de ADN purificado se observó mediante un gel de agarosa y se procedió a enviar esta muestra amplificada para su secuenciación. El proceso de secuenciación se realizó en el Laboratorio Nacional de Genómica para la Biodiversidad (LANGEBIO) del Centro de Investigación y Estudios Avanzados (CINVESTAV), Unidad Irapuato, Guanajuato, México, del Instituto
Tween 80 were added, except for depletion of $C$ $(\mathrm{HdB}<\mathrm{C})$ to which glycerol was limited to $0.08 \%(\mathrm{v} / \mathrm{v})$. For the experiments in which nitrogen depletion was required $(\mathrm{HdB}<\mathrm{N})$, $\left(\mathrm{NH}_{4}\right)_{2} \mathrm{SO}_{4}$ was used at a concentration 100 times lower $(0.15 \mathrm{mM})$ than the utilized for $\mathrm{HdB}$ minimal medium. For the experiments limited 100 times lower in $\mathrm{Pi}(\mathrm{HdB}<\mathrm{Pi}), \mathrm{K}_{2} \mathrm{HPO}_{4}$ was added at a final concentration of 0.089 $\mathrm{mM}$ (0.0155 $\mathrm{g} \mathrm{L}^{-1}$ ) and $\mathrm{NaH}_{2} \mathrm{PO}_{4}$, at a concentration of $0.0708 \mathrm{mM}\left(0.085 \mathrm{~g} \mathrm{~L}^{-1}\right)$, for replacing the loss of buffer capacity, 3-(Nmorpholino) propanesulfonic acid (MOPS) 50 $\mathrm{mM}$ was added(24). The growth and stationary phases of all cultures were monitored at 600 $\mathrm{nm}$ (OD600), until $144 \mathrm{~h}$ and final $\mathrm{pH}$ was recorded.

The predicted fragment incorporating esat- 6 gene was obtained by amplification of M. smegmatis genomic DNA, using primers: F-5'ACAGGTATGGA ATTTCGCCG-3', R-5'-CAGGCAAACATTCCCGTGA-3', which were designed using the Oligo TM Software DNA Star Program. For conducting the identification by enzymatic sequencing, the amplified product was purified by a protocol based on silica columns (QIAquick Gel Extraction Kit, QIAGEN囚); the amplified fragment was observed in agarose gel at $1.2 \%$ through a UV- light transilluminator and it was cut with a sterile scalpel, carrying out the aforementioned protocol. The quality and quantity of purified DNA was observed by agarose gel and this amplified sample was sent for sequencing. This process was carried out at the Laboratorio Nacional de Genómica para la Biodiversidad (LANGEBIO) of the Centro de Investigación y Estudios Avanzados (CINVESTAV), Unidad Irapuato, Guanajuato, México, of the Instituto Politécnico Nacional (IPN), based on the ddNTPs method(25), using the $3730 \mathrm{XL}$ DNA sequencer (Applied Biosystems, Foster City, CA) and the kit Big Dye Terminator 3.1 (Applied Biosystems, Foster City, CA).

For RNA extraction, M. smegmatis culture was adapted to the corresponding culture media until the beginning of the stationary phase (96 h). 
Politécnico Nacional (IPN), basado por el método ddNTPs(25), utilizando un secuenciador 3730 XL DNA, (Applied Biosystems, Foster City, CA) y el kit Big Dye Terminator 3.1 (Applied Biosystems, Foster City, CA).

Para la extracción de ARN el cultivo de $M$. smegmatis se adaptó en los medios de cultivo correspondientes hasta el inicio de la fase estacionaria (96 h). En esta fase se cosechó el $30 \%$ de las células, se lavaron con PBS y se colocaron en $150 \mathrm{ml}$ de medio de cultivo fresco con las mismas condiciones nutritivas, se incubaron por $14 \mathrm{~h}$. El ARN se extrajo mediante el uso de TRIzol (Invitrogen ${ }^{\circledR}$ ). Se observó por electroforesis en geles de agarosa $(1.2 \%)$ con MOPS X (200 mM de MOPS, $50 \mathrm{mM}$ de acetato de sodio, y $10 \mathrm{mM}$ de EDTA, pH 7) y $3.15 \%$ de formaldehído. La electroforesis se corrió en una solución amortiguadora TAE $(40 / 1 \mathrm{mM} \mathrm{pH}$ 8.0).

La hibridación Northern se efectuó a partir de 8 a $12 \mathrm{ng}$ del ARN extraído, transferido por capilaridad descendente en membranas de nailon, en citrato de sodio y cloruro de sodio 20X. El ARN se fijó con luz ultravioleta durante 5 min. La sonda se elaboró a partir del fragmento del gen esat-6 amplificado por PCR y marcada con biotina acoplada a fosfatasa alcalina (Gene Images Alkphos Direct Labelling and Detection System-GE Health Care $\left.{ }^{\circledR}\right)$. La hibridación se efectuó durante toda la noche y se reveló por autoradiografía (Hyperfilm-MP autoradiography, Amersham Pharmacia Bioscience $\left.{ }^{\circledR}\right)(26)$.

Los datos obtenidos del crecimiento y $\mathrm{pH}$, se obtuvieron de seis repeticiones y se aplicó la prueba $t$ de student, para expresar los resultados de la media, el error estándar de la media y las correspondientes comparaciones entre ellas de todos los cultivos de $M$. smegmatis(27).

En los medios de cultivo probados, se observó a $M$. smegmatis con crecimiento más bajo en los medios $\mathrm{HdB}<\mathrm{N}, \mathrm{HdB}<\mathrm{C}(0.659$ y 1.697$)$
In this phase, $30 \%$ of cells were cultured, washed with PBS and placed in $150 \mathrm{~mL}$ of fresh culture medium under the same nutritional conditions and they were incubated for $14 \mathrm{~h}$. RNA was extracted using TRIzol (Invitrogen $($ ); it was observed by electrophoresis in agarose gels $(1.2 \%)$ using MOPS $X(200 \mathrm{mM}$ of MOPS, $50 \mathrm{mM}$ of sodium acetate and $10 \mathrm{mM}$ of EDTA, $\mathrm{pH} 7$ ), and $3.15 \%$ of formaldehyde. Electrophoresis was ran in TAE buffer solution (40/1 mM pH 8.0).

Northern blot hybridization was performed starting from 8 to $12 \mathrm{ng}$ of extracted RNA, capillary transferred onto nylon membranes, sodium citrate and sodium chloride 20X. DNA was fixed using ultraviolet light for $5 \mathrm{~min}$. The probe was derived from fragments of esat- 6 gene, amplified by PCR and labelled as biotinylated alkaline phosphatase (Gene Images Alkphos Direct Labelling and Detection SystemGE Health Care $\AA$ ). Hybridization was performed all night and was revealed by autoradiography (Hyperfilm-MP autoradiography, Amersham Pharmacia Bioscience $囚)^{(26)}$.

The growth and $\mathrm{pH}$ data were obtained from six repetitions and Student's $t$ - test was used to express the results of the mean, standard error of the mean and corresponding comparisons between all M. smegmatis cultures(27).

In the testing culture media, $M$. smegmatis was observed with lower growth in $\mathrm{HdB}<\mathrm{N}, \mathrm{HdB}<\mathrm{C}$ (0.659 and 1.697) media, in comparison to $\mathrm{HdB}$ minimal culture and $\mathrm{HdB}<\mathrm{Pi}$ (2.170 and 1.982) $(P<0.05)$. In addition, $M$. smegmatis in $\mathrm{HdB}<\mathrm{Pi}$ has similar growth in $\mathrm{HdB}$ minimal culture $(P>0.05)$ (Figure 1$)$. This is indicative of a continuous growth in spite of stress conditions due to a decrease 100 times Pi. With the exception of $\mathrm{HdB}<\mathrm{Pi}$ culture, in the rest of the testing and control media used, M. smegmatis resume its growth while changing it to a fresh culture medium, after $144 \mathrm{~h}$ of culture.

In $\mathrm{HdB}<\mathrm{Pi}$ culture medium, a relationship between growth, loss of acid-alcohol resistance 
Héctor M. López-Pérez, et al. / Rev Mex Cienc Pecu 2016;7(1):127-139

Figura 1. M. smegmatis crecido a $144 \mathrm{~h}$ en los medios de cultivo usados para el experimento $\mathrm{HdB}<\mathrm{N}(0.659 \pm 0.12)$, Sauton (1.559 \pm 0.03$), \mathrm{HdB}<\mathrm{C}(1.697 \pm 0.07), \mathrm{HdB}<\mathrm{Pi}$ (1.982 \pm 0.11$) \mathrm{HdB}$ mínimo (2.170 \pm 0.12$)$ y $7 \mathrm{H} 9(2.638 \pm 0.12)$

Figure 1. M. smegmatis grown until $144 \mathrm{~h}$ in culture media used for experiments: $\mathrm{HdB}<\mathrm{N}$ (0.659 \pm 0.12$)$, Sauton (1.559 \pm 0.03$), \mathrm{HdB}<\mathrm{C}(1.697 \pm 0.07), \mathrm{HdB}<\mathrm{Pi}(1.982 \pm 0.11) \mathrm{HdB}$ minimal $(2.170 \pm 0.12)$ and $7 \mathrm{H} 9(2.638 \pm 0.12)$

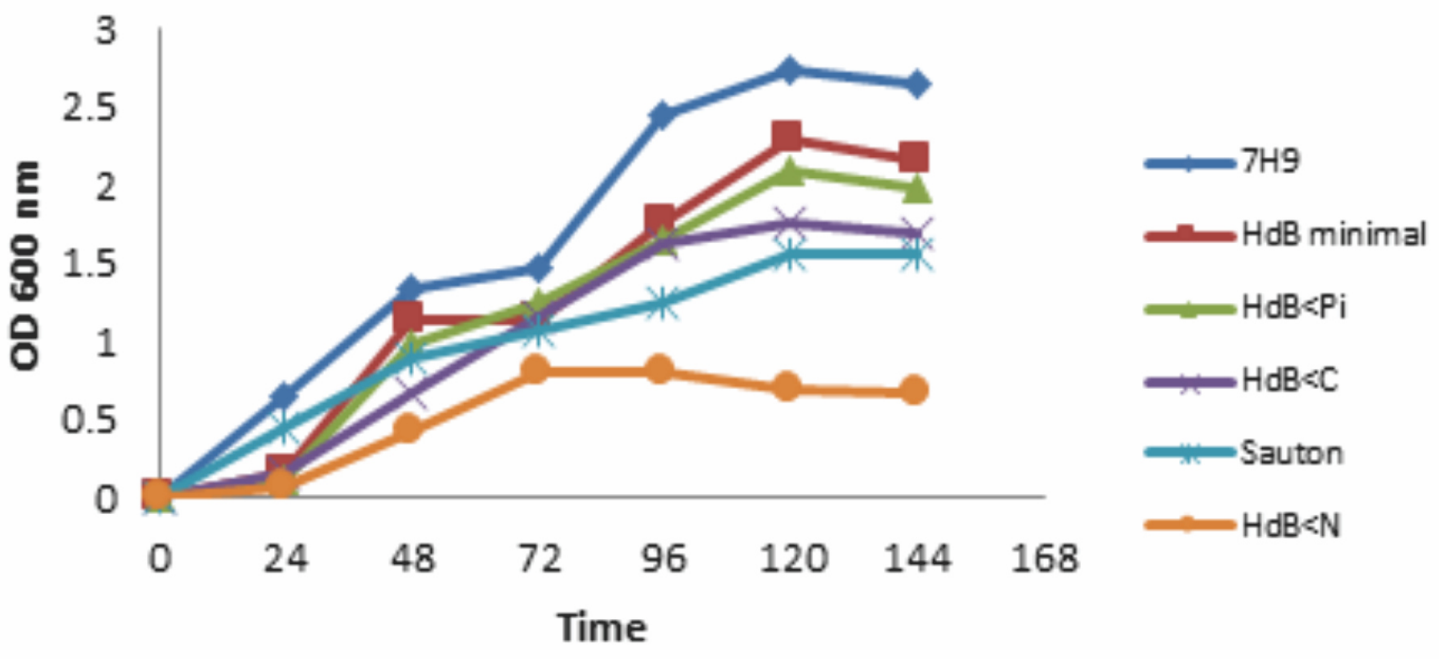

respecto al medio de cultivo $\mathrm{HdB}$ mínimo y $\mathrm{HdB}<\mathrm{Pi}(2.170$ y 1.982$)(P<0.05)$. Además, $M$. smegmatis en $\mathrm{HdB}<\mathrm{Pi}$ tiene un crecimiento similar al cultivo en HdB mínimo $(P>0.05)$ (Figura 1). Lo que es indicativo de un crecimiento continuo a pesar de las condiciones de estrés por la disminución de 100 veces $\mathrm{Pi}$. Con excepción del cultivo en $\mathrm{HdB}<\mathrm{Pi}$, en los demás medios de cultivo probados y los usados como controles, $M$. smegmatis reanuda su crecimiento al cambiarlo al medio de cultivo fresco correspondiente, después de 144 h de cultivo.

En el medio de cultivo $\mathrm{HdB}<\mathrm{Pi}$ se observó una relación entre el crecimiento de $M$. smegmatis, el $\mathrm{pH}$ y la pérdida de resistencia alcohol-ácido. Es decir, a mayor número de horas de cultivo $(144 \mathrm{~h})$, se disminuyó el pH (5.4 \pm 0.16$)$, aunado a la incapacidad de recuperar su actividad metabólica cuando se cambia el cultivo a medio fresco. Esto se observó por los cúmulos de células teñidas con el color característico de la técnica Ziehl-Neelsen desaparecen partir de of $M$. smegmatis, and $\mathrm{pH}$ was observed. That is, by higher number of culture hours (144), $\mathrm{pH}$ was decreased (5.4 \pm 0.16$)$, and the mycobacteria showed incapacity to recuperate its metabolic activity when the culture was changed to a fresh medium. This was observed in cumulus cells stained with the characteristic color of Ziehl-Neelsen technique, which disappeared from $100 \mathrm{~h}$, until all cells were stained blue-colored (Figures $2 a$ and 2b).

With the exception of $\mathrm{HdB}<\mathrm{Pi}$ culture medium, mycobacteria in limited nutrient culture media have a slow growth until they reach the stationary phase. Additionally, bacteria grown in $\mathrm{HdB}<\mathrm{P}$ gradually lose their resistance to acidalcohol from $96 \mathrm{~h}$, not recovering it until $144 \mathrm{~h}$ of culture, when bacteria were changed to fresh medium. For which the $96 \mathrm{~h}$ were taken into consideration for changing $M$. smegmatis to fresh culture media, extract total RNA after $12 \pm 1 \mathrm{~h}$ (Figure 3A) and perform Northern hybridization. This assay reveals that $M$. smegmatis cultured in $\mathrm{HdB}<\mathrm{C}, \mathrm{HdB}<\mathrm{N}$ and $\mathrm{HdB}$ 
Figura 2. M. smegmatis a) Pérdida de resistencia alcohol-ácido en cultivo $\mathrm{HdB}<\mathrm{Pi}$ a 96 horas.

b) mismo cultivo cambiado a medio fresco 1 hora después, en el que se observa la recuperación de la capacidad de respuesta al alcohol-ácido

Figure 2. M. smegmatis a) Loss of acid-alcohol resistance in $\mathrm{HdB}<\mathrm{Pi}$ culture medium through 96 h. b) Same culture changed to fresh medium $1 \mathrm{~h}$ after, where recovery of capacity of response to acid-alcohol is observed

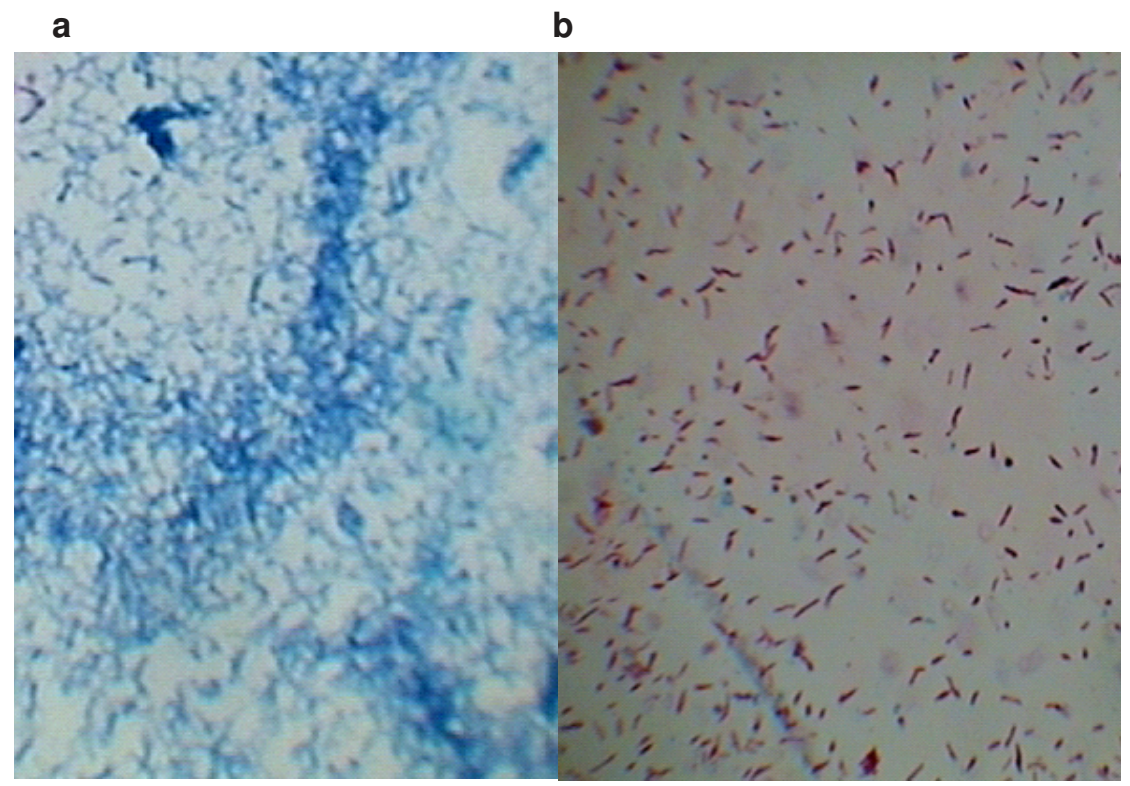

las $100 \mathrm{~h}$ hasta teñirse todas las células de color azul (Figuras $2 a$ y $2 b$ ).

Con excepción del medio $\mathrm{HdB}<\mathrm{Pi}$, las micobacterias en los medios de cultivo restringidos en nutrientes tienen un menor crecimiento hasta la fase estacionaria. Además, las bacterias crecidas en $\mathrm{HdB}<\mathrm{Pi}$ pierden paulatinamente su capacidad de resistencia al alcohol-ácido a partir de las $96 \mathrm{~h}$, para no volver a recuperarla después de $144 \mathrm{~h}$ de cultivo, cuando las bacterias se cambiaron a medio fresco. Por lo que las $96 \mathrm{~h}$ se tomaron en cuenta para hacer los cambios de M. smegmatis a medios de cultivo fresco de todas las pruebas, extraer el ARN total $12 \pm 1 \mathrm{~h}$ después (Figura 3A) y llevar a cabo la hibridación Northern. Esta prueba revela que $M$. smegmatis cultivado en $\mathrm{HdB}<\mathrm{C}, \mathrm{HdB}<\mathrm{N}$, y $\mathrm{HdB}$ medio mínimo, no expresa el gen esat-6. Sin embargo, el cultivo limitado 100 veces en Pi (Figura 3B carril 7) si minimal medium, does not express esat- 6 gene. However, the culture limited 100 times in Pi (Figure 3B, lane 7) did showed the expression, in a similar way as the culture media used as control (7H9 and Sauton, lanes 1 and 3, Figure 3B).

The probe elaborated from esat- 6 fragment was sequenced and was referred to GeneBank number SeqID KR363260. The homology comparison consulted on the database corresponds to esat- 6 gene and is located in site 87387 to $87604 \mathrm{pb}$ of the complete genome sequencing of $M$. smegmatis strain MC2155 (ID: gb|CP000480.1).

The mycobacterial capacity to accumulate energy sources, allows them to in vivo persist the infection phase(28). In this sense, in vitro mycobacteria achieve to adapt to nutrient depletion and survive for more than $650 \mathrm{~d}(24)$, due to energy accumulation of the stored 
se observó la expresión, de manera similar a los medios de cultivo usados como control (7H9 y Sauton carriles 1 y 3 de la Figura 3B).

La sonda elaborada a partir del fragmento de esat-6, se secuenció y se remitió al GeneBank con el número SeqID KR363260. La comparación homológica consultada en la base de datos corresponde al gen esat- 6 , y se localiza en el sitio del 87,387 a $87,604 \mathrm{pb}$ de la secuencia del genoma completo de $M$. smegmatis cepa MC2155 (ID: gb|CP000480.1).

La capacidad que poseen las micobacterias para acumular las fuentes de energía, les permiten persistir in vivo durante la fase de infección(28). En este mismo sentido, las micobacterias in vitro logran adaptarse al agotamiento de los nutrientes y sobrevivir por más de 650 días(24), debido a la acumulación de energía de los compuestos almacenados y de la degradación de proteínas innecesarias y ARNm bacteriano(6). Esto puede provocar una situación emergente, en la cual las micobacterias responden al compounds and degradation of unnecessary proteins and bacterial RNA(6). This can cause an emergency situation, where mycobacteria respond to the environment through genes which regulate adequate changes to the conditions imposed. Thus, the model of the present study allows to observe esat- 6 gene expression of $M$. smegmatis in $\mathrm{HdB}<\mathrm{Pi}$.

The adaptation of M. smegmatis for up to $144 \mathrm{~h}$ is evident in all culture media, with the exception of the mycobacteria grown in $\mathrm{HdB}<\mathrm{Pi}$ (Figure 1). For which it poses instability of the bacteria to the culture, because of its continuous growth with respect to the $\mathrm{HdB}$ minimal medium $(P>0.05)$ and its inactive metabolism after $144 \mathrm{~h}$ when changing the mycobacteria to a fresh culture, where the loss of acid-alcohol capacity is observed (Figure 2: $a$ and b); similar results in M. tuberculosis were obtained by Rifat et a(29), when limiting $\mathrm{Pi}$ in $7 \mathrm{H} 9$ medium.

This suggests, under the proposed conditions, the existence of a state of emergency, in which

Figura 3. M. smegmatis A) ARN total de la bacteria en los medios de cultivo: 1) 7H9, 2) HdB medio mínimo, 3) Sauton sin Zinc, 4) variable no controlada 5) $\mathrm{HdB}<\mathrm{N}, 6) \mathrm{HdB}<\mathrm{C}$, 7) $\mathrm{HdB}<\mathrm{Pi}$.

B) Mismos carriles con los resultados de la hibridación Northern para el gen esat-6

Figure 3. M. smegmatis A) Total RNA of the bacteria in culture media: 1) $7 \mathrm{H} 9$, 2) $\mathrm{HdB}$ minimal culture, 3) Sauton without zinc, 4) not controlled variable 5) $\mathrm{HdB}<\mathrm{N}, 6) \mathrm{HdB}<\mathrm{C}, 7) \mathrm{HdB}<\mathrm{Pi}$.

B) Same lanes with the results of Northern hybridization for esat- 6 gene

A)

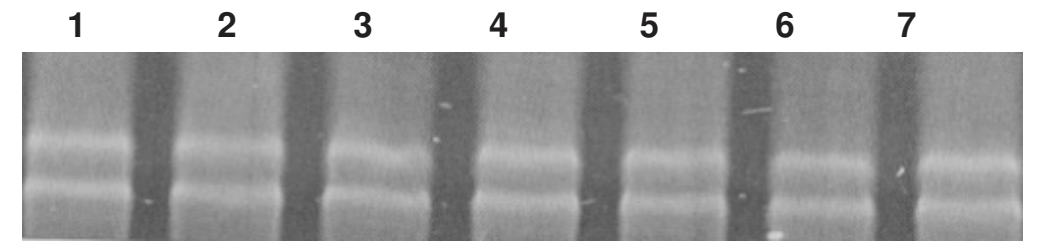

B)

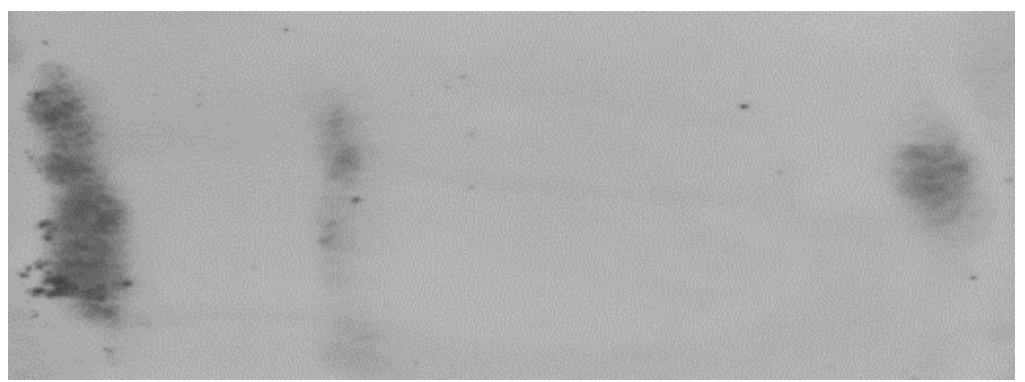


ambiente a través de los genes que regulan los cambios adecuados a las condiciones impuestas. De esta manera, el modelo del presente estudio permite observar la expresión del gen esat- 6 de $M$. smegmatis en $\mathrm{HdB}<\mathrm{Pi}$.

La adaptación de M. smegmatis hasta por $144 \mathrm{~h}$ es evidente en todos los medios de cultivo, excepto para las micobacterias crecidas por en $\mathrm{HdB}<\mathrm{Pi}$ (Figura 1). Por lo cual se plantea la inestabilidad de la bacteria al cultivo, por su crecimiento continuo con respecto al cultivo en HdB mínimo ( $P>0.05)$ y su metabolismo inactivo después de $144 \mathrm{~h}$ al cambiar las micobacterias a un medio de cultivo fresco, en donde se observa la pérdida de la capacidad alcohol-ácido (Figura 2: $a$ y b), resultados similares a los de Rifat et a(29) al restringir Pi en medio 7H9 en el crecimiento de M. tuberculosis.

Esto hace suponer bajo las condiciones propuestas, la existencia del estado de emergencia, en el cual M. smegmatis puede tener diferentes formas de adaptación, donde se comprometen diversas rutas de transducción mediante los cuales las micobacterias detectan y dan una respuesta al medio. Estas rutas, pueden estar relacionados con la alarmona ppGpp que desencadena la respuesta estricta. Un mecanismo indispensable para la adaptación de las bacterias durante la transición de la fase exponencial a la fase estacionaria(30-32). Al respecto, en $E$. coli, la carencia de aminoácidos, carbono, o Pi, se acompaña por el incremento de los niveles de ppGpp y se observan acumulaciones de polifosfatos $(33,34)$.

Bajo las condiciones limitantes de $\mathrm{Pi}$ y un crecimiento sostenido muy cercano al HdB medio mínimo (Figura 1), M. smegmatis aparentemente termina los recursos externos y las reservas de energía interna. Para evitar este desgaste de las reservas de energía se ha propuesto la respuesta estricta, que se caracteriza por la regulación de ppGpp, que incrementa la ciclopropanación(35), la inhibición y síntesis de los ácidos grasos y los fosfolípidos(36). Aunque la propuesta de la respuesta estricta está
M. smegmatis can have different forms of adaptation, where several signal transduction pathways are involved by which mycobacteria detect and give response to the environment. These pathways can be associated with alarmone, which triggers the stringent response. An indispensable mechanism for bacterial adaptation during the transition of the exponential phase to the stationary phase(30-32). In this regard, in $E$. coli, lack of amino acids, carbon or $\mathrm{Pi}$, is followed by an increase in ppGpp levels and polyphosphate accumulation $(33,34)$.

Under limiting conditions of $\mathrm{Pi}$ and a sustained growth very near to $\mathrm{HdB}$ minimal medium (Figure 1), M. smegmatis apparently finishes the external sources and the internal energy reserves. In order to avoid this wear down of energy reserves, the stringent response has been proposed, which is characterized by ppGpp regulation that increases cyclopropanation(35), inhibition and synthesis of fat acids and phospholipids(36). Although the proposal of the stringent response is associated with the possibility of stabilization of the metabolism for adaptation of mycobacteria to stress conditions, that is, under conditions of abundance, polyphosphates can be used as donors of ADP, GDP and other reactions in which the Rel enzyme is involved, acting in the synthesis and hydrolysis of ppGpp $(5,37)$. However, when there are not enough Pi reserves and energy reserves are minimal, it is probable that the stringent response fails so that $M$. smegmatis adapts and its metabolic state does not let it respond immediately to favorable changes to renew its growth, as it happened in the present study.

An increase in ppGpp levels and polyphosphates induces the transcription of 150 genes involved in the slowdown of growth and metabolism(38). Rather, what has been found in this study with respect to $\mathrm{Pi}$ limitation in $\mathrm{HdB}$, is that growth is maintained similar to $\mathrm{HdB}$ minimal medium $(P<0.05)$, where $\mathrm{Pi}$ is not limited. Conversely, the esat- 6 gene expression in $\mathrm{HdB}<\mathrm{Pi}$ that occurred at mRNA level (Figure 3B), which is comparable to $7 \mathrm{H} 9$ and Sauton, although the 
relacionada con la posibilidad de la estabilización del metabolismo para la adaptación de la micobacteria a las condiciones de estrés, es decir, bajo condiciones de abundancia, los polifosfatos pueden servir como donadores de ADP, GDP, y otras reacciones en las que se involucra la enzima Rel que actúa en la síntesis e hidrólisis de ppGppp $(5,37)$. Pero cuando no hay suficientes reservas de $\mathrm{Pi}$ y las reservas de energía son mínimas, es probable que la respuesta estricta falle para que $M$. smegmatis se adapte, y su estado metabólico no le permita responder de inmediato a los cambios favorables para reanudar su crecimiento, como lo sucedido en el presente estudio.

Un incremento en los niveles de ppGpp y polifosfatos induce la transcripción de 150 genes involucrados en la disminución del crecimiento y el metabolismo(38). Por el contrario, lo encontrado en la presente investigación respecto a la limitación de $\mathrm{Pi}$ en $\mathrm{HdB}$, es que se mantiene el crecimiento, similar al del medio HdB mínimo en el que no se restringe el $\mathrm{Pi}(P<0.05)$. Por otra parte, la expresión de gen esat- 6 en $\mathrm{HdB}<\mathrm{Pi}$ que se dio a nivel de los ARNm (Figura 3B), que es comparable a $7 \mathrm{H} 9$ y Sauton, aunque la proteína codificada por este gen, se secreta sólo en el medio Sauton(22), lo que falta por determinar es si bajo las condiciones de cultivo $\mathrm{HdB}<\mathrm{Pi}$ se secreta la proteína ESAT-6. Esta proteína, también se ha propuesto como una ATPasa(39), que modifica las propiedades del compartimiento del fagosoma donde reside $M$. tuberculosis, como lo evidenciado por la retención aberrante o adquisición defectuosa de un rango de proteínas del hospedero, entre las que se incluyen las Rab GTPasas $(40,41)$ y la protón-ATPasa de la vacuola(42).

En M. smegmatis y M. tuberculosis, los polifosfatos regulan la síntesis de ppGpp a través del control de la transcripción de relA vía la ruta $m p r A-s i g E-r e l A(37,43)$. Existen otros sistemas de los dos componentes que pueden contribuir a la regulación de relA. Por lo que se plantea como perspectivas, estudiar las relaciones entre los reguladores de la expresión protein encoded by this gene is only secreted in Sauton medium(22), it is necessary to determine whether under $\mathrm{HdB}<\mathrm{Pi}$ culture conditions, esat- 6 protein is secreted. This protein has also been proposed as an ATPase(39), which modifies the properties of the phagosome compartment, where $M$. tuberculosis reside, as evidenced by aberrant retention or imperfect acquisition of a range of proteins of the host, including Rab GTPases $(40,41)$ and vacuolar $(\mathrm{H}+)$-ATPase $(42)$.

In M. smegmatis and M. tuberculosis, polyphosphates regulate ppGpp synthesis through transcriptional control of relA via mprAsigE-relA pathway $(37,43)$. There are other systems of the two components that can contribute to the regulation of relA. Consequently, it is proposed as prospect to study the relationships between regulators of $\mathrm{Pi}$ dependent gene expression, including SenX3RegX3 and its relationship with genes that regulate the ESX-1 system and secretion of the proteins in $M$. smegmatis(44). Pang et al(45) confirm that in $M$. tuberculosis, esat- 6 is not regulated by MprAB under growth in standard 7H9. Therefore, it is important to understand whether esat- 6 of $M$. smegmatis is regulated by this system under Pi-limiting conditions. The studies of Rifat et al(29), focused on Pi limitation, show that esat- 6 does not express in $M$. tuberculosis, when they limited $\mathrm{Pi}$ in $7 \mathrm{H} 9$ medium with L-glutamate as source of organic nitrogen; however, in this model, Pi is limited and the nitrogen source is inorganic. Pang et a(45) also report that at least there is an indirect regulation of ESX-1 by PhoPR. Thereon, it is suggested to research the relationships between Pi limitation and PhoPR, under the proposed model in this research.

In conclusion, $M$. smegmatis adapts to $\mathrm{HdB}$ minimal medium, $\mathrm{HdB}<\mathrm{C}$ and $\mathrm{HdB}<\mathrm{N}$, and resumes its metabolic activity in fresh medium, but it does not express esat- 6 gene. However, in $\mathrm{HdB}<\mathrm{Pi}$ medium, $M$. smegmatis shows a continuous exponential growth phase, statistically similar to $\mathrm{HdB}$ medium $(P<0.05)$, 
de los genes que dependen de Pi. Entre ellos, está SenX3-RegX3 y su relación con los genes que regulan el sistema ESX-1 y las proteínas de secreción en $M$. smegmatis(44). Pang et al(45), confirman que en $M$. tuberculosis, esat- 6 no es regulado por MprAB bajo crecimiento en $7 \mathrm{H} 9$ normal. Por lo que se debe entender si esat- 6 de $M$. smegmatis es regulado por este sistema en condiciones limitantes de $\mathrm{Pi}$. Al respecto, los estudios de Rifat et al(29), enfocados a la restricción de $\mathrm{Pi}$, demuestran que no se expresa esat- 6 en $M$. tuberculosis, cuando restringieron el Pi en medio 7H9 con L-glutamato como fuente de nitrógeno orgánico; sin embargo, en este modelo se limita el Pi y la fuente de nitrógeno es inorgánico. Pang et a(45) también indican que al menos indirectamente hay una regulación del ESX-1 por PhoPR. Por lo que se propone investigar las relaciones entre la limitación de Pi y PhoPR, bajo el modelo propuesto en esta investigación.

En conclusión, M. smegmatis se adapta a $\mathrm{HdB}$ medio mínimo, $\mathrm{HdB}<\mathrm{C}$ y $\mathrm{HdB}<\mathrm{N}$ y reanuda su actividad metabólica en medio fresco, pero no expresa el gen esat-6. En cambio el medio de cultivo $\mathrm{HdB}<\mathrm{Pi}$, M. smegmatis presenta una fase de crecimiento exponencial continuo, estadísticamente similar al de HdB medio mínimo $(P<0.05)$, manifiesta un estado metabólico en el cual pierde su capacidad ácido-resistente en la fase estacionaria y expresa el gen esat- 6 después del cambio del medio de cultivo a $96 \mathrm{~h}$ al medio de cultivo fresco correspondiente. Por lo anterior se propone al modelo de investigación para la expresión génica en condiciones de estrés por nutrientes.

\section{AGRADECIMIENTOS}

A la Dra. Clara Espitia Pinzón del Instituto Nacional de Investigaciones Biomédicas de la UNAM por la aportación de la cepa $M$. smegmatis mc ${ }^{2} 155$. A la comunidad del Centro de Innovación y Desarrollo Educativo y el Centro de Estudios Justo Sierra. manifesting a metabolic state in which it loses resistant-acid capacity in the stationary phase and expresses the esat- 6 gene after changing the culture medium to $96 \mathrm{~h}$ into the corresponding fresh culture medium. Consequently, the model of research for genetic expression under nutrient stress conditions is proposed.

\section{ACKNOWLEDGEMENTS}

Special thanks to Dr. Clara Espitia Pinzon at the Instituto Nacional de Investigaciones Biomédicas of the UNAM for the contribution of $M$. smegmatis strain $\mathrm{mc}^{2} 155$ and to the community of the Centro de Innovación y Desarrollo Educativo and Centro de Estudios Justo Sierra, Sinaloa State.

End of english version

\section{LITERATURA CITADA}

1. Parish T, Smith DA, Kendall S, Casali N, Bancroft GJ, Stoker NG. Deletion of two-component regulatory systems increases the virulence of Mycobacterium tuberculosis. Infect Immun 2003;71(3):1134-40.

2. de Jonge MI, Pehau-Arnaudet G, Fretz MM, Romain F, Bottai $D$, Brodin $\mathrm{P}$, et al. ESAT-6 from Mycobacterium tuberculosis dissociates from its putative chaperone CFP-10 under acidic conditions and exhibits membrane-lysing activity. J Bacteriol 2007;189(16):6028-34.

3. Rohde $\mathrm{KH}$, Abramovitch RB, Russell DG. Mycobacterium tuberculosis invasion of macrophages: linking bacterial gene expression to environmental cues. Cell Host Microbe 2007;2(5):352-64.

4. Abramovitch RB, Rohde $\mathrm{KH}$, Hsu FF, Russell DG. aprABC: a Mycobacterium tuberculosis complex-specific locus that modulates $\mathrm{pH}$-driven adaptation to the macrophage phagosome. Mol Microbiol 2011;80(3):678-94.

5. Dahl JL, Kraus CN, Boshoff HI, Doan B, Foley K, Avarbock $\mathrm{D}$, et al. The role of RelMtb-mediated adaptation to stationary phase in long-term persistence of Mycobacterium tuberculosis in mice. Proc Natl Acad Sci USA 2003;100(17):10026-31.

6. Siegele DA, Kolter R. Life after log. J Bacteriol 1992;174(2):345-8.

7. Gebhard S, Humpel A, McLellan AD, Cook GM. The alternative sigma factor SigF of Mycobacterium smegmatis is required for survival of heat shock, acidic $\mathrm{pH}$ and oxidative stress. Microbiology 2008;154(Pt 9):2786-95. 
8. Humpel A, Gebhard S, Cook GM, Berney M. The SigF regulon in Mycobacterium smegmatis reveals roles in adaptation to stationary phase, heat, and oxidative stress. J Bacteriol 2010;192(10):2491-2502.

9. Slonczewski JL, Rosen BP, Alger JR, Macnab RM. pH homeostasis in Escherichia coli: measurement by ${ }^{31 \mathrm{P}}$ nuclear magnetic resonance of methylphosphonate and phosphate. Proc Natl Acad Sci USA 1981;78(10):6271-6275.

10. Pepin CA, Wood HG. Polyphosphate glucokinase from Propionibacterium shermanii. Kinetics and demonstration that the mechanism involves both processive and nonprocessive type reactions. J Biol Chem 1986;261(10):4476-4480.

11. Lyon RH, Rogers $\mathrm{P}, \mathrm{Hall} \mathrm{WH}$, Lichtein $\mathrm{HC}$. Inducible glutamate transport in Mycobacteria and its relation to glutamate oxidation. J Bacteriol 1967;94(1):92-100.

12. Sritharan V, Ratledge C, Wheeler PR. Effect of homoserine on growth of Mycobacterium smegmatis: inhibition of glutamate transport by homoserine. J Gen Microbiol 1987;133(10):2781-2785.

13. Malhotra V, Tyagi JS, Clark-Curtiss JE. DevR-mediated adaptive response in Mycobacterium tuberculosis H37Ra: links to asparagine metabolism. Tuberculosis (Edinb) 2009;89(2):169-174.

14. Ganguly N, Giang PH, Gupta C, Basu SK, Siddiqui I, Salunke DM, et al. Mycobacterium tuberculosis secretory proteins CFP-10, ESAT-6 and the CFP10:ESAT6 complex inhibit lipopolysaccharide-induced NF-kappaB transactivation by down regulation of reactive oxidative species (ROS) production. Immunol Cell Biol 2008;86(1):98-106.

15. Welin A, Eklund D, Stendahl O, Lerm M. Human macrophages infected with a high burden of ESAT-6-expressing $M$. tuberculosis undergo caspase-1- and cathepsin Bindependent necrosis. PLoS One 2011;6(5):e20302.

16. Flint JL, Kowalski JC, Karnati PK, Derbyshire KM. The RD1 virulence locus of Mycobacterium tuberculosis regulates DNA transfer in Mycobacterium smegmatis. Proc Natl Acad Sci USA 2004;101(34):12598-12603.

17. GenBank of National Center for Biotechnology Information. <http://blast.ncbi.nlm.nih.gov/Blast.cgi\#alnHdr_118 168627>.

18. Cox RA, Garcia MJ. Adaptation of mycobacteria to growth conditions: a theoretical analysis of changes in gene expression revealed by microarrays. PLoS One 2013;8(4):e59883.

19. Ojha AK, Mukherjee TK, Chatterji D. High intracellular level of guanosine tetraphosphate in Mycobacterium smegmatis changes the morphology of the bacterium. Infect Immun 2000;68(7):4084-4091.

20. Berthet FX, Rasmussen PB, Rosenkrands I, Andersen P, Gicquel B. A Mycobacterium tuberculosis operon encoding ESAT-6 and a novel low-molecular-mass culture filtrate protein (CFP-10). Microbiology 1998;144(Pt 11):3195-3203.

21. Brodin P, Majlessi L, Marsollier L, de Jonge MI, Bottai D, Demangel C, et al. Dissection of ESAT- 6 system 1 of Mycobacterium tuberculosis and impact on immunogenicity and virulence. Infect Immun 2006;74(1):88-98.

22. Converse SE, Cox JS. A protein secretion pathway critical for Mycobacterium tuberculosis virulence is conserved and functional in Mycobacterium smegmatis. J Bacteriol 2005;187(4):1238-1245.
23. Lamarche MG, Wanner BL, Crepin S, Harel J. The phosphate regulon and bacterial virulence: a regulatory network connecting phosphate homeostasis and pathogenesis. FEMS Microbiol Rev 2008;32(3):461-473.

24. Smeulders MJ, Keer J, Speight RA, Williams HD. Adaptation of Mycobacterium smegmatis to stationary phase. J Bacteriol 1999;181(1):270-283.

25. Sanger F, Nicklen $S$, Chase AR. DNA sequencing with chain terminating inhibitors. Proc Natl Acad Sci 1977;74(12):54635468.

26. Sambrook J, Russell DW. The condensed protocols from Molecular cloning: a laboratory manual. Cold Spring Harbor, NY: Cold Spring Harbor Laboratory Press; 2006:420-478.

27. Dowdy S. Weardon S. Chilko D. Statistics for research. Chapter 8: Student's t distribution. Third ed. New Jersey: John Wiley \& Sons, Inc.; 2004:178-210.

28. Gomez JE, McKinney JD. M. tuberculosis persistence, latency, and drug tolerance. Tuberculosis (Edinb) 2004;84(1-2):2944.

29. Rifat D, Bishai WR, Karakousis PC. Phosphate depletion: a novel trigger for Mycobacterium tuberculosis persistence. J Infect Dis 2009;200(7):1126-1135.

30. Artsimovitch I, Patlan V, Sekine S, Vassylyeva MN, Hosaka $\mathrm{T}$, Ochi $\mathrm{K}$, et al. Structural basis for transcription regulation by alarmone ppGpp. Cell 2004;117(3):299-310.

31. Gralla JD. Escherichia coli ribosomal RNA transcription: regulatory roles for ppGpp, NTPs, architectural proteins and a polymerase-binding protein. Mol Microbiol 2005;55(4):973977.

32. Costanzo A, Ades SE. Growth phase-dependent regulation of the extracytoplasmic stress factor, sigmaE, by guanosine 3',5'-bispyrophosphate (ppGpp). J Bacteriol 2006;188(13): 4627-4634.

33. Ahn K, Kornberg A. Polyphosphate kinase from Escherichia coli. Purification and demonstration of a phosphoenzyme intermediate. J Biol Chem 1990;265(20):11734-11739.

34. Spira B, Yagil E. The relation between ppGpp and the PHO regulon in Escherichia coli. Mol Gen Genet 1998;257(4):469477.

35. Eichel J, Chang YY, Riesenberg D, Cronan JE, Jr. Effect of ppGpp on Escherichia coli cyclopropane fatty acid synthesis is mediated through the RpoS sigma factor (sigmaS). J Bacteriol 1999;181(2):572-576.

36. Heath RJ, Jackowski S, Rock CO. Guanosine tetraphosphate inhibition of fatty acid and phospholipid synthesis in Escherichia coli is relieved by overexpression of glycerol-3phosphate acyltransferase (plsB). J Biol Chem 1994;269(42):26584-26590.

37. Sureka K, Dey S, Datta P, Singh AK, Dasgupta A, Rodrigue $\mathrm{S}$, et al. Polyphosphate kinase is involved in stress-induced mprAB-sigE-rel signalling in mycobacteria. Mol Microbiol 2007;65(2):261-276.

38. Hengge-Aronis R. Signal transduction and regulatory mechanisms involved in control of the sigma(S) (RpoS) subunit of RNA polymerase. Microbiol Mol Biol Rev 2002;66(3):373-395.

39. Pallen MJ. The ESAT-6/WXG100 superfamily - and a new Gram-positive secretion system? Trends Microbiol 2002;10(5):209-212. 


\section{ADAPTACIÓN DE M. SMEGMATIS Y SU EFECTO EN LA EXPRESIÓN DE ESAT-6}

40. Via LE, Deretic D, Ulmer RJ, Hibler NS, Huber LA, Deretic V. Arrest of mycobacterial phagosome maturation is caused by a block in vesicle fusion between stages controlled by rab5 and rab7. J Biol Chem 1997;272(20):13326-13331.

41. Clemens DL, Lee BY, Horwitz MA. Deviant expression of Rab5 on phagosomes containing the intracellular pathogens Mycobacterium tuberculosis and Legionella pneumophila is associated with altered phagosomal fate. Infect Immun 2000;68(5):2671-2684.

42. Sturgill-Koszycki S, Schlesinger $\mathrm{PH}$, Chakraborty $\mathrm{P}$, Haddix $\mathrm{PL}$, Collins $\mathrm{HL}$, Fok AK, et al. Lack of acidification in Mycobacterium phagosomes produced by exclusion of the vesicular proton-ATPase. Science 1994;263(5147):678-681.
43. Manganelli R, Voskuil MI, Schoolnik GK, Smith I. The Mycobacterium tuberculosis ECF sigma factor sigmaE: role in global gene expression and survival in macrophages. Mol Microbiol 2001;41(2):423-437.

44. Glover RT, Kriakov J, Garforth SJ, Baughn AD, Jacobs WR, Jr. The two-component regulatory system senX3-regX3 regulates phosphate-dependent gene expression in Mycobacterium smegmatis. J Bacteriol 2007;189(15):54955503.

45. Pang X, Samten $B$, Cao G, Wang X, Tvinnereim AR, Chen XL, et al. MprAB Regulates the espA Operon in Mycobacterium tuberculosis and Modulates ESX-1 Function and Host Cytokine Response. J Bacteriol 2013;195(1):66-75. 
